\title{
PENGUNGKAPAN CORPORATE SOCIAL RESPONSIBILITY (SURVEI PADA PERUSAHAAN YANG TERMASUK DALAM INDEKS SRI KEHATI)
}

\author{
Akram \\ Animah \\ Prayitno Basuki
}

\begin{abstract}
Abstrak
Abstract

The objective of this study is to examine the influence of corporate governance mechanism on the disclosure of CSR. Studies conducted on the companies included in the SRI KEHATI index during 2011-2014. The study obtained 18 companies as sample of this study. The results of multiple linear regression analysis showed that the audit committee and independent commissioner have no influence on the disclosure of CSR, while institutional ownership was found to have influence on the disclosure of CSR. The study implies that the stakeholders are able to change the dimensions of CSR implementation, whereby previously it was only for humanitarian and environmental aspects, CSR is now able to increase its profit and finally the goal to sustainability can be manifested.
\end{abstract}

Keyword: independent directors, audit committee, institutional ownership, disclosure of corporate social responsibility

\section{PENDAHULUAN}

Pada tahun 2009 PT. Bursa Efek Indonesia bekerja sama dengan Yayasan Keaneka Ragaman Hayati Indonesia (KEHATI) meluncurkan indeks harga saham yang mengacu pada tata cara dari SRI (Sustainable Responsible Investment ) yang diberi nama SRI-KEHATI. Dalam indeks tersebut terdapat 25 perusahaan terbaik yang telah melakukan CSR (Corporate Social Responsibility) sesuai dengan prinsip-prinsip SRI dan kriteria seleksi yang telah ditentukan oleh Bursa Efek dan Yayasan KEHATI. Review dan penggantian emiten yang masuk dalam perhitungan indeks SRI-KEHATI dilakukan 2 kali dalam setahun, yaitu setiap hari Bursa pertama bulan Februari dan Agustus.

SRI-KEHATI (Sustainable Responsible Investment-KEHATI) indeks merupakan indikator atau cerminan pergerakan harga saham yang menjadi 
pedoman bagi investor terhadap saham pada emiten-emiten yang memiliki kinerja yang sangat baik secara berkelanjutan dalam menjalankan good corporate governance dan memiliki kesadaran terhadap keberlangsungan lingkungan hidup, pemberdayaan masyarakat sekitar serta tetap menjalankan etika dalam berbisnis.

CSR merupakan salah satu kewajiban yang harus dipenuhi oleh perusahaan. CSR dimanfaatkan untuk memperluas dampak positif hasil industri terhadap masyarakat, dalam arti sempit CSR digunakan sebagai alat untuk memperbaiki citra dan mengurangi risiko atas tekanan public akibat dampak yang ditimbulkan.

Pelaksanaan CSR oleh perusahaan diungkapkan dalam laporan tahunan ataupun laporan keberlanjutan perusahaan. Dalam pelaksanaan program CSR yang dilakukan oleh sebuah perusahaan tidak tentu sama dengan perusahaan lainnya. Terdapat beberapa jenis indikator yang paling sering digunakan untuk menilai pengungkapan CSR yang telah dilakukan oleh perusahaan, antara lain: ISO 26000, PROPER atau Program Penilaian Peringkat Kinerja Perusahaan dalam Pengelolaan Lingkungan Hidup, dan GRI.

Penerapan CSR secara konsisten akan membangun hubungan yang harmonis dengan masyarakat serta menumbuhkan kepercayaan masyarakat dan mitra bisnis (Faqih, 2010). Oleh karena itu perusahaan memerlukan suatu mekanisme untuk menjalankan aktivitasnya termasuk dalam melakukan tanggung jawab sosialnya yang sesuai dengan prinsip good corporate governance. Mekanisme corporate governance yang ditunjang dengan profitabilitas yang cukup, maka perusahaan dapat melakukan tanggung jawab sosial yang bermanfaat untuk legitimasi dari masyarakat (Sembiring, 2005).

Kepemilikan institusional yang merupakan salah satu mekanisme corporate governance dapat bertindak sebagai pengawas perusahaan, semakin besar kepemilikan institusional dalam perusahaan, maka tekanan terhadap manajemen perusahaan untuk mengungkapkan tanggung jawab sosial pun semakin besar. Hal ini berarti kepemilikan institusional dapat mendorong perusahaan untuk meningkatkan pengungkapan CSR (Anggraini, 2006).

Mekanisme corporate governance lainnya adalah Dewan Komisaris Independen dan komposisi Komite Audit. Komisaris independen yang tidak terafiliasi dengan manajemen tidak hanya mengawasi dan mengontrol manajemen untuk kepentingan shareholders tapi mereka juga mengontrol kepentingan stakeholders yang berupa tanggung jawab sosial perusahaan (Nurkhin, 2010). Komposisi Komite Audit yang dimiliki perusahaan minimal 
terdiri dari tiga orang, dimana sekurang-kurangnya satu orang berasal dari Komisaris Independen dan dua orang lainnya berasal dari luar emiten (Siswantaya, 2007).

Penelitian tentang mekanisme corporate governance maupun corporate social responsibility cukup banyak diteliti antara lain oleh Rustiarini (2010) membuktikan bahwa pengungkapan CSR dan pengungkapan corporate governance berpengaruh signifikan pada nilai perusahaan. Hasil penelitian ini menunjukkan bahwa salah satu tujuan pelaksanaan corporate governance adalah untuk mendorong timbulnya tanggung jawab perusahaan terhadap masyarakat dan lingkungan. Febriyanti (2011) menemukan bahwa perusahaan telah melaksanakan CSR yang sesuai dengan prinsip GCG yaitu prinsip responsibility yang dipertegas dengan pelaksanaan CSR yang berkelanjutan dan semakin baik dan terstruktur dari tahun ke tahun. Nurkhin (2009) membuktikan kepemilikan institusional tidak berpengaruh positif terhadap pengungkapan tanggung jawab sosial sedangkan Dewan Komisaris Independen terbukti positif dan signifikan terhadap pengungkapan tanggung jawab sosial.

Tujuan penelitian ini adalah untuk menguji apakah mekanisme corporate governance yang diproksikan dengan Kepemilikan institusional, Komisaris Independen, Komposisi Komite Audit berpengaruh terhadap pengungkapan corporate social responsibility.

\section{KERANGKA TEORITIS DAN PENGEMBANGAN HIPOTESIS}

\section{Teori Stakeholders}

Konsep tanggung jawab sosial perusahaan telah mulai dikenal sejak awal 1970an, yang secara umum dikenal dengan stakeholders theory artinya sebagai kumpulan kebijakan dan praktik yang berhubungan dengan stakeholders, nilai-nilai perusahaan, pemenuhan ketentuan hukum, penghargaan terhadap masyarakat dan lingkungan, serta komitmen dunia usaha untuk berkontribusi dalam pembangunan secara berkelanjutan.

Teori stakeholders mengatakan bahwa perusahaan bukanlah entitas yang hanya beroperasi untuk kepentingannya sendiri namun harus memberikan manfaat bagi stakeholdemya. Dengan demikian, keberadaan suatu perusahaan sangat dipengaruhi oleh dukungan yang diberikan oleh stakeholder sehingga aktivitas perusahaan juga perlu mempertimbangkan persetujuan dari stakeholder (Ghozali dan Chariri, 2007) dalam (Febriyanti, 2010).

Tekanan dari berbagai pihak memaksa perusahaan untuk menerima tanggung jawab atas dampak aktivitas bisnisnya terhadap masyarakat. 
Perusahaan dihimbau untuk bertanggung jawab terhadap pihak yang lebih luas daripada kelompok pemegang saham dan kreditur saja (Sembiring, 2005). Menurut Handayani (2010) ada beberapa alasan yang mendorong perusahaan perlu memperhatikan kepentingan stakeholder, yaitu :

1. Isu lingkungan melibatkan kepentingan berbagai kelompok dalam masyarakat yang dapat mengganggu kualitas hidup mereka.

2. Era globalisasi telah mendorong produk-produk yang diperdagangkan harus bersahabat dengan lingkungan.

3. Para investor dalam menanamkan modalnya cenderung untuk memilih perusahaan yang memiliki dan mengembangkan kebijakan dan program lingkungan.

Menurut Ghozali dan Chariri (2007) dalam Febriyanti (2010) stakeholder pada dasarnya dapat mengendalikan atau memiliki kemampuan untuk mempengaruhi pemakaian sumber-sumber ekonomi yang digunakan perusahaan. Hal tersebut dapat berupa kemampuan untuk membatasi pemakaiaan sumber ekonomi yang terbatas (modal dan tenaga kerja), akses terhadap media yang berpengaruh, kemampuan untuk mengatur perusahaan, atau kemampuan untuk mempengaruhi konsumsi atas barang dan jasa yang dihasilkan perusahaan. Oleh karena itu, ketika stakeholder mengendalikan sumber ekonomi yang terpenting bagi perusahaan, maka perusahaan akan bereaksi dengan cara-cara yang dapat memuaskan keinginan stakeholder agar hubungan perusahaan dengan stakeholder tetap terjalin dengan baik

\section{Pengaruh Kepemilikan Institusional terhadap Corporate Social Responsibility}

Penelitian Anggraini (2006) menunjukkan bahwa semakin besar kepemilikan institusional dalam perusahaan maka tekanan terhadap manajemen perusahaan untuk mengungkapkan tanggung jawab sosial pun semakin besar. Investor institusional memiliki power dan experience serta bertanggungjawab dalam menerapkan prinsip corporate governance untuk melindungi hak dan kepentingan seluruh pemegang saham sehingga mereka menuntut perusahaan untuk melakukan komunikasi secara transparan. Dengan demikian, kepemilikan institusional dapat meningkatkan kualitas dan kuantitas pengungkapan sukarela. Hal ini berarti kepemilikan institusional dapat mendorong perusahaan untuk meningkatkan pengungkapan CSR. Berdasarkan uraian di atas, dapat disusun hipotesis sebagai berikut :

$\mathrm{H}_{1}$ : Kepemilikan Institusional berpengaruh terhadap Pengungkapan Corporate Social Responsibility 


\section{Pengaruh Komisaris Independen terhadap Corporate Social Responsibility}

Keberadaan Dewan Komisaris Independen di Indonesia diatur dengan Ketentuan Bapepam dan Peraturan Bursa Efek Indonesia No. 1-A tanggal 14 Juli tahun 2004. Berdasarkan aturan tersebut, jumlah Dewan Komisaris Independen minimal adalah $30 \%$ dari jumlah dewan komisaris keseluruhan. Ketentuan ini memberikan pengaruh terhadap pengendalian dan pengawasan terhadap manajemen dalam operasi perusahaannya, diantaranya adalah pengungkapan tanggung jawab sosial perusahaan (Nurkhin, 2010). Dengan wewenang yang dimiliki, komisaris dapat memberikan pengaruh yang cukup kuat untuk menekan manajemen untuk mengungkapkan CSR sehingga perusahaan yang memiliki Dewan Komisaris yang lebih besar akan lebih banyak mengungkapkan CSR. Berdasarkan uraian di atas, dapat disusun hipotesis sebagai berikut :

$\mathrm{H}_{2}$ : Komisaris Independen berpengaruh terhadap pengungkapan Corporate Social Responsibility

\section{Pengaruh Komposisi Komite Audit terhadap Corporate Social Responsibility}

Keputusan Ketua Bapepam Nomor Kep-29/PM/2004 yang termuat dalam peraturan Nomor IX.I.5 disebutkan bahwa Komite Audit yang dimiliki perusahaan minimal terdiri dari tiga orang, dimana sekurang-kurangnya satu orang berasal dari Komisaris Independen dan dua orang lainnya berasal dari luar emiten. Jumlah anggota Komite Audit harus disesuaikan dengan kompleksitas perusahaan dengan tetap memperhatikan efektifitas dalam pengambilan keputusan (Siswantaya, 2010).

Keberadaan Komite Audit dapat mempengaruhi pengungkapan yang dilakukan perusahaan. Komite Audit merupakan komite yang bertugas membantu Dewan Komisaris dalam melakukan mekanisme pengawasan terhadap manajemen sehingga dapat meningkatkan pengungkapan informasi perusahaan. Salah satu tugas dari Komite Audit adalah membantu manajemen untuk mengevaluasi resiko-resiko yang dihadapi perusahaan termasuk di dalamnya tanggung jawab social perusahaan (Waryanto,2010).

Komposisi Komite Audit yang sesuai dengan Keputusan Ketua Bapepam Nomor Kep-29/PM/2004 yang termuat dalam peraturan Nomor IX.I.5 yang mengharuskan dua orang lain dari luar emiten diharapkan dapat melakukan pengawasan lebih baik dan kualitas pengungkapan informasi social yang dilakukan perusahaan semakin meningkat. Berdasarkan uraian di atas, dapat disusun hipotesis sebagai berikut : 
Akram, Animah, \& Prayitno Basuki : Pengungkapan Corporate Social...

$\mathrm{H}_{3}$ : Komposisi Komite Audit berpengaruh terhadap Pengungkapan Corporate Social Responsibility

\section{METODE PENELITIAN}

\section{Jenis dan Sumber Data}

Jenis data penelitian ini adalah data kuantitatif dengan sumber dari data yang dipublikasikan oleh Bursa Efek Indonesia yang diperoleh dari Indonesian Capital Market Directory 2011-2014 serta laporan tanggung jawab sosial perusahaan (CSR Report), laporan keberlanjutan (Sustainability Report) maupun laporan tahunan (Annual Report) yang dipublikasikan melalui internet untuk tahun 2011-2014 dari masing-masing situs perusahaan atau melalui situs idx.co.id.

\section{Populasi, Sampel dan Teknik Pengambilan Sampel}

Populasi dalam penelitian ini adalah perusahaan yang masuk dalam Indeks SRI- KEHATI yang terdaftar di Bursa Efek Indonesia (BEI) pada periode 2011-2014. Sampel dipilih berdasarkan metode purposive dengan pertimbangan bahwa perusahaan yang diteliti selalu konsisten masuk dalam indeks SRI-KEHATI dari tahun 2011-2014 sejumlah 18 perusahaan, jadi jumlah observasi yaitu 72 (4x 18 perusahaan).

\section{Definisi Operasional Variabel}

Berdasarkan perumusan masalah yang telah ditentukan maka variabelvariabel yang akan dianalisis dalam penelitian ini dapat diidentifikasi sebagai berikut :

1. Mekanisme Corporate Governance

Dalam penelitian ini proksi untuk mengukur Mekanisme Corporate Governance menggunakan :

- Komisaris Independen

Komisaris Independen adalah anggota komisaris yang tidak terafiliasi dengan manajemen, anggota dewan komisaris lainnya dan pemegang saham pengendali, serta bebas dari hubungan bisnis atau hubungan lainnya yang dapat mempengaruhi kemampuannya untuk bertindak independen atau bertindak semata-mata demi kepentingan perusahaan (Nurkhin, 2009).

Komisaris Independen $=\frac{\text { jumlah anggota komisaris yang berasal dari pihak luar }}{\text { jumlah keseluruhan anggota komisaris }}$

- Komposisi Komite Audit

Komposisi Komite Audit diukur dengan menghitung anggota Komite Audit yang berasal dari pihak independen di luar emiten dibagi jumlah 
keseluruhan Komite Audit dalam laporan tahunan perusahaan (Waryanto, 2010).

- Kepemilikan Institusional

Kepemilikan institusional adalah jumlah kepemilikan saham oleh pihak institusi. Kepemilikan institusional memiliki kemampuan untuk mengendalikan pihak manajemen melalui proses monitoring (Siswantaya, 2007).

Kepemilikan institusional $=\frac{\text { jumlah saham yang dimiliki investor institusional }}{\text { jumlah keseluruhan saham yang beredar }}$

Kepemilikan manajerial tidak digunakan dalam penelitian ini karena perusahaan sampel yang memiliki kepemilikan manajerial kurang dari 50\% dari jumlah keseluruhan sampel.

2. Corporate Social Responsibility

Menurut Suharto (2009) dalam Nilawaty (2011) definisi CSR adalah kepedulian perusahaan yang menyisihkan sebagian keuntungannya (profit) bagi kepentingan pembangunan manusia (people) dan lingkungan (planet) secara berkelanjutan berdasarkan prosedur (procedure) yang tepat dan profesional. Kualitas Pengungkapan CSR akan dihitung berdasarkan prinsipprinsip yang ditetapkan pada G4 Guideline (Reporting Principles for Defining Quality) oleh GRI (Freundlieb\&Teuteberg, 2012). Setiap pengujian yang dinilai telah terpenuhi akan diberi skor 1 (satu) dan total skor yang diperoleh akan dibagi dengan total pengujian sehingga diperoleh indeks.

\section{Prosedur Analisis Data}

Peneliti menggunakan variabel pengungkapan CSR sebagai variabel dependen sedangkan variabel independen yang digunakan adalah mekanisme corporate governance (Komisaris independen, komposisi komite audit, kepemilikan institusional). Teknik analisis data yang digunakan dalam penelitian ini adalah metode regresi linier berganda melalui program SPSS dengan tingkat signifikansi pada confidence level 95\% dengan alfa 0,05. Model yang akan digunakan untuk menguji hipotesis dalam penelitian ini adalah regresi linier berganda (Multiple Regression Analysis). Model yang ditawarkan adalah:

Di mana:

$$
\text { CSR }=\alpha+\beta \text { Kep.ins }+\beta \text { Kom. ind }+\beta \text { Komp.K. } A+\varepsilon
$$

Keterangan :

CSR = Corporate Social Responsibility

$\alpha \quad=$ Konstanta

$\beta \quad=$ Koefisien Regresi

Kep.ins $\quad=$ Kepemilikan Institusional

Kom.ind $=$ Komisaris Independen 
Komp. K.A= Komposisi Komite Audit

$e \quad=$ Kesalahan (error)

Model penelitian ini akan diestimasi dengan menggunakan teknik Ordinary Least Square (OLS) karena itu, diperlukan pengujian ekonometrik (uji asumsi klasik) multikolonearitas, autokorelasi dan heteroskedastisitas Hipotesis pada penelitian ini akan diuji dengan melakukan:

a. Uji $\mathrm{F}$ untuk mengetahui apakah kelayakan model penelitian di mana kriteria pengujiannya adalah menolak $\mathrm{HO}$ jika $\mathrm{p}$-value $(\mathrm{sig})<\mathrm{a}$. Bila signifikansi lebih tinggi daripada tingkat keyakinan $(a=0,05)$, berarti seluruh variabel independen tidak secara bersama-sama memiliki pengaruh yang signifikan terhadap variabel dependen. Sebaliknya, bila signifikansi lebih kecil dari tingkat keyakinan $(a=0,05)$, berarti seluruh variabel independen secara bersama-sama mempunyai pengaruh yang signifikan terhadap variabel dependen.

b. Uji t-statistik untuk mengetahui pengaruh parsial masing-masing variabel independen terhadap variabel dependen di mana kriteria pengujian adalah menolak $\mathrm{HO}$ jika $\mathrm{p}$-value $(\mathrm{sig})<\mathrm{a}$. Bila signifikansi lebih tinggi daripada tingkat keyakinan $(a=0,05)$, berarti variabel independen tidak memiliki pengaruh yang signifikan terhadap variabel dependen. Sebaliknya, bila signifikansi lebih kecil dari tingkat keyakinan $(a=0,05)$, berarti variabel independen mempunyai pengaruh yang signifikan terhadap variabel dependen.

\section{HASIL DAN PEMBAHASAN}

\section{Gambaran Umum Objek Penelitian}

Populasi dalam penelitian ini adalah perusahaan yang masuk dalam Indeks SRI- KEHATI yang terdaftar di Bursa Efek Indonesia (BEI) pada periode 2011-2014. Sampel dipilih dengan metode judgement sampling. Setelah dilakukan proses seleksi berdasarkan karakteristiknya diperoleh sampel sebanyak 18 perusahaan, dengan periode pengamatan selama empat tahun, maka jumlah observasi dalam penelitian berjumlah 72 observasi.

\section{Statistik Deskriptif}

Statistik deskriptif dalam penelitian ini memberikan gambaran atau informasi mengenai variabel-variabel penelitian, yaitu komisaris independen, komite audit, kepemilikan institusional dan CSR yang dilihat dari nilai minimum, maksimum, rata-rata (mean), dan standar deviasi. Berikut ini disajikan ringkasan data-data dalam bentuk statistik deskriptif untuk masingmasing variabel. 
Tabel 1 Statistik Deskriptif

\begin{tabular}{l|l|l|l|l|l|l|}
\hline & $\mathrm{N}$ & Minimum & Maximum & Mean & Std. Deviation \\
\cline { 2 - 7 } & Kom_Ind & 72 & .20 & .80 & .4663 & .14804 \\
Uji & Kom_Aud & 72 & .20 & 1.00 & .6343 & .16375 \\
As & Kep_Inst & 72 & .23 & 1.00 & .6167 & .16656 \\
um & CSR_GRI4 & 72 & .80 & 1.00 & .9389 & .07230 \\
si \\
Kla \\
sik
\end{tabular}

Uji asumsi klasik berguna untuk memberikan kepastian bahwa persamaan regresi yang didapatkan memiliki ketepatan dalam estimasi, tidak bias dan konsisten. Hasil uji asumsi klasik dari model regresi yang digunakan dalam penelitian ini adalah sebagai berikut.

\section{Uji Normalitas}

Uji normalitas dilakukan untuk menguji apakah dalam model regresi, variabel pengganggu atau residual memiliki distribusi normal. Uji Normalitas dalam penelitian ini menggunakan uji statistik non-parametrik Kolmogorov Smirnov (K-S). Pengambilan kesimpulan dalam pengujian ini dapat dilihat dari nilai signifikansinya. Data dikatakan terdistribusi secara normal apabila nilai signifikansinya lebih besar dari 0,05 (5\%). Hasil uji normalitas disajikan sebagai berikut.

Tabel 2 Hasil Uji Normalitas

\begin{tabular}{|l|l|}
\hline & Unstandardized Residual \\
\hline $\mathrm{N}$ & 72 \\
\hline $\begin{array}{l}\text { Kolmogorov-Smirnov } \\
\mathrm{Z}\end{array}$ & 1.630 \\
\hline Asymp. Sig. (2-tailed) & .010 \\
\hline
\end{tabular}

Berdasarkan hasil uji pada tabel 4.2 dapat dilihat bahwa besarnya nilai Kolmogorov-Smirnov (K-S) adalah 1,630 dengan signifikansi sebesar 0,010. Nilai tersebut berada dibawah nilai signifikansi 0,05 (5\%), sehingga dapat disimpulkan bahwa data tidak terdistribusi secara normal. 
Akram, Animah,\& Prayitno Basuki : Pengungkapan Corporate Social...

\section{Uji Multikolonieritas}

Uji multikolonieritas bertujuan untuk menguji apakah dalam model regresi ditemukan adanya korelasi antar variabel bebas (Independen). Model regresi yang baik tidak terjadi korelasi antar variabel independen (bebas dari masalah multikolonieritas). Uji multikolonieritas dalam penelitian ini dilakukan dengan melihat nilai tolerance dan Variance Inflation Factor (VIF) pada model regresi. Model regresi dikatakan bebas dari masalah multikolonieritas apabila nilai tolerance memiliki nilai lebih besar dari 0,10 dan VIF memiliki nilai lebih kecil dari 10. Hasil uji multikolonieritas disajikan sebagai berikut.

Tabel 3 Hasil uji Multikolonieritas

\begin{tabular}{|l|l|l|}
\hline \multirow{2}{*}{ Model } & \multicolumn{2}{|c|}{ Collinearity Statistics } \\
\cline { 2 - 3 } & Tolerance & VIF \\
\hline Kom_Aud & .794 & 1.259 \\
\hline Kom_Ind & .937 & 1.067 \\
\hline Kep_Inst & .810 & 1.234 \\
\hline
\end{tabular}

Hasil Uji Multikolonieritas pada tabel 4.3 menunjukkan bahwa semua variabel independen memiliki nilai tolerance lebih dari 0,10 dan nilai VIF tidak lebih besar dari 10, sehingga dapat disimpulkan bahwa model regresi tidak mengalami masalah multikolonieritas.

\section{Uji Autokorelasi}

Uji autokorelasi dilakukan untuk menguji apakah dalam suatu model regresi terdapat korelasi antara kesalahan pengganggu pada periode $\mathrm{t}$ dengan kesalahan pengganggu pada periode t-1 (sebelumnya). Jika terjadi korelasi maka terjadi masalah autokorelasi. Autokorelasi muncul karena observasi yang berurutan sepanjang waktu berkaitan satu sama lain. Uji autokorelasi dalam penelitian ini dilakukan dengan menggunakan uji DurbinWatson (DW). Model regresi dikatakan tidak mengalami autokorelasi jika nilai Durbin-Watson berada diantara du dan $4-$ du atau du $<\mathrm{d}<4-$ du. Hasil uji autokorelasi disajikan sebagai berikut.

Table 4.4

Hasil Uji Autokorelasi

\begin{tabular}{|l|l|}
\hline Model & Durbin-Watson \\
\hline 1 & 1.974 \\
\hline
\end{tabular}


Hasil uji Durbin Watson pada tabel 4.4 menunjukkan bahwa nilai Durbin Watson adalah sebesar 1,974. Hasil nilai DW tersebut dapat dibandingkan dengan tabel Durbin-Watson d Statistic : Significance point for $d l$ and $d u$ at 0,05 level of significance dalam mengambil sebuah keputusan hasil autokorelasi. Jumlah data yang digunakan adalah $72(n=72)$ dan jumlah variabel independennya adalah $3(\mathrm{k}=3)$. Nilai dl dan du untuk $\mathrm{n}=72$ dan $\mathrm{k}=3$ pada level alpha $5 \%$ adalah masing- masing 1,561 dan 1,675.

Nilai DW pada hasil pengujian autokorelasi adalah sebesar 1,974. Nilai tersebut berada di antara nilai du dan 4-du, jika dimasukkan ke dalam rumus du $<$ d $<4$ - du maka hasilnya 1,675 < 1,974 < 4-1,675 = 1,863 <2,106 < 2,325, artinya nilai DW 1,974 lebih besar dari batas atas (du) 1,675 dan kurang dari 2,325, sehingga dapat disimpulkan bahwa keputusan tidak terdapat autokorelasi positif atau negatif antar residual pada model regresi dan model regresi layak digunakan.

\section{Uji Heteroskedastisitas}

Model regresi yang baik adalah model yang homoskedastisitas atau tidak terjadi heteroskedastisitas. Penelitian ini menggunakan uji Glejser untuk mendeteksi heteroskedastisitas. Ghozali (2006 : 108) menjelaskan bahwa uji Glejser meregresi nilai absolut residual sebagai variabel dependen dengan variabel independen, jika probabilitas signifikannya di atas tingkat kepercayaan $5 \%$ maka model regresi tidak mengandung heteroskedastisitas. Hasil uji heteroskedastisitas disajikan sebagai berikut.

Tabel 5. Hasil Uji Heteroskedastisitas

\begin{tabular}{|l|l|l|}
\hline \multicolumn{1}{|c|}{ Model } & \multicolumn{1}{c|}{$\mathrm{t}$} & \multicolumn{1}{c|}{ Sig. } \\
& & \\
\hline (Constant) & 1.243 & .218 \\
\hline Kom_Aud & -.161 & .872 \\
\hline Kom_Ind & .739 & .462 \\
\hline Kep_Inst & .708 & .482 \\
\hline
\end{tabular}

Hasil uji Glejser pada tabel 5 menunjukkan bahwa seluruh variabel independen signifikan secara statistik mempengaruhi variabel dependen dengan tingkat signifikansi sebesar 0,872, 0,462 dan 0,482 yang jauh diatas tingkat signifikansi 0,05 sehingga terbebas dari masalah heteroskedastisitas.

\section{Analisis Regresi}

Peneliti menggunakan variable pengungkapan CSR sebagai variabel dependen sedangkan variabel independen yang digunakan adalah 
mekanisme corporate governance (Komisaris independen, komposisi komite audit, kepemilikan institusional). Teknik analisis data yang digunakan dalam penelitian ini adalah metode regresi linier berganda melalui program SPSS dengan tingkat signifikansi pada confidence level 95\% dengan alfa 0,05. Model yang akan digunakan untuk menguji hipotesis dalam penelitian ini adalah regresi linier berganda (Multiple Regression Analysis). Hasil regresi dari persamaan regresi adalah sebagai berikut:

Tabel 6. Hasil Regresi

\begin{tabular}{|l|l|l|l|l|l|}
\hline Model & \multicolumn{2}{|l|}{$\begin{array}{l}\text { Unstandardized } \\
\text { Coefficients }\end{array}$} & $\begin{array}{l}\text { Standardize } \\
\text { d } \\
\text { Coefficients }\end{array}$ & T & Sig. \\
\cline { 2 - 6 } & B & Std. Error & Beta & & \\
\hline (Constant) & 1.012 & .066 & & 15.37 & .000 \\
& & & & 5 & \\
\hline Kom_Aud & -.027 & .069 & -.052 & -.398 & .692 \\
\hline Kom_Ind & .037 & .059 & .075 & .622 & .536 \\
\hline Kep_Inst & -.118 & .057 & -.273 & -2.093 & .040 \\
\hline
\end{tabular}

Berdasarkan tabel di atas dapat disimpulkan bahwa persamaan regresi dalam penelitian ini menjadi :

$$
\text { CSR }=\alpha-0,118 \text { Kep.ins }+0,037 \text { Kom. ind }-0,027 \text { Komp. K. } A+\varepsilon
$$

\section{Hasil Pengujian Hipotesis Uji Simultan (Uji statistik F)}

Pengujian uji $\mathrm{F}$ digunakan untuk melihat variabel independen atau bebas secara simultan berpengaruh terhadap variabel terikat. Pengambilan keputusan dari hasil pengujian statistik $\mathrm{F}$ dapat dilihat dari nilai signifikansi yang dihasilkan. Apabila nilai signifikansinya lebih besar dari nilai signifikansi yang ditetapkan $5 \%$ atau 0,05 maka dapat disimpulkan bahwa HO diterima dan Ha ditolak. Sebaliknya, apabila nilai signifikansinya lebih kecil dari $5 \%$ atau 0,05 maka HO ditolak dan Ha diterima. Adanya pengaruh variabel independen secara simultan terhadap variabel dependen jika nilai signifikansi yang dihasilkan lebih kecil dari $5 \%$ atau 0,05 . Hasil pengujian statistik $F$ diuraikan sebagai berikut.

Tabel 7. Hasil Uji Simultan (Uji Statistik F)

\begin{tabular}{|l|l|l|l|l|l|}
\hline Model & $\begin{array}{l}\text { Sum of } \\
\text { Squares }\end{array}$ & Df & $\begin{array}{l}\text { Mean } \\
\text { Square }\end{array}$ & F & Sig. \\
\hline Regression & .024 & 3 & .008 & 1.597 & $.198^{\mathrm{a}}$ \\
\hline Residual & .347 & 68 & .005 & & \\
\hline Total & .371 & 71 & & & \\
\hline
\end{tabular}


Hasil uji Anova atau $\mathrm{F}$ test pada tabel 4.11 menghasilkan nilai $\mathrm{F}$ hitung sebesar 1,597 dengan tingkat signifikansi 0,198. Hasil ini menunjukkan nilai signifikansi berada di atas 5\%, sehingga dapat disimpulkan bahwa model regresi dapat dengan komisaris independen, komposisi komite audit dan kepemilikan institusional sebagai variable independen tidak memiliki pengaruh secara bersama-sama atau simultan terhadap corporate social responsibility sebagai variabel dependen.

\section{Uji Parsial (Uji Statistik t)}

Pengujian uji $t$ digunakan untuk menguji kemaknaan variabel independen atau bebas secara parsial terhadap variabel terikat melalui uji regresi. Regresi dilakukan dengan menggunakan analisis regresi berganda. Pengambilan keputusan dari hasil pengujian ini dapat dilihat dari nilai signifikansi yang dihasilkan dari masing-masing variabel independen yaitu komite audit, komisaris independen, kepemilikan institusional. Apabila nilai signifikansi t-hitung yang dihasilkan lebih besar dari 5\% atau 0,05 maka dapat disimpulkan bahwa $\mathrm{HO}$ diterima dan Ha ditolak. Sebaliknya, apabila nilai signifikansi t-hitung yang dihasilkan lebih kecil dari 5\% atau 0,05 maka HO ditolak dan Ha diterima. Hasil uji statistik t atau uji parsial diuraikan sebagai berikut.

Tabel 8. Hasil Uji Parsial (Uji Statistik t)

\begin{tabular}{|c|c|c|c|c|c|c|}
\hline \multirow{6}{*}{$\begin{array}{l}\qquad \text { Be } \\
\text { rdasark } \\
\text { an tabel } \\
\text { diatas } \\
\text { dapat } \\
\text { terlihat } \\
\text { bahwa } \\
\text { nilai }\end{array}$} & \multirow[b]{2}{*}{ Model } & \multicolumn{2}{|c|}{$\begin{array}{l}\text { Unstandardized } \\
\text { Coefficients }\end{array}$} & $\begin{array}{l}\text { Standardized } \\
\text { Coefficients }\end{array}$ & \multirow[t]{2}{*}{$\mathrm{t}$} & \multirow[t]{2}{*}{ Sig. } \\
\hline & & B & $\begin{array}{l}\text { Std. } \\
\text { Error }\end{array}$ & Beta & & \\
\hline & (Constant) & 1.012 & .066 & & $\begin{array}{l}15.37 \\
5\end{array}$ & .000 \\
\hline & Kom_Aud & -.027 & .069 & -.052 & -.398 & .692 \\
\hline & Kom_Ind & .037 & .059 & .075 & .622 & .536 \\
\hline & Kep_Inst & -.118 & .057 & -.273 & -2.093 & .040 \\
\hline
\end{tabular}

signifikansi dari komposisi auditor yaitu 0,692 lebih besar dari 0,05 yang berarti bahwa komposisi komite audit tidak berpengaruh secara signifikan terhadap pengungkapan corporate social responsibility, begitu pula dengan komisaris independen yang memiliki nilai signifikansi melebihi 0,05 yaitu 0,536 sehingga dapat disimpulkan bahwa komisaris independen tidak berpengaruh secara signifikan terhadap pengungkapan corporate social responsibility. Sebaliknya berbeda dengan kepemilikan institusional yang memiliki nilai dibawah 0,05 yaitu sebesar 0,04, sehingga dapat disimpulkan 
bahwa kepemilikan institusional berpengaruh signifikan terhadap pengungkapan corporate social responsibility.

Berdasarkan hasil pengujian hipotesis maka didapatkan hasil bahwa hipotesis satu yang menyatakan bahwa kepemilikan institusional berpengaruh terhadap pengungkapan corporate social responsibility diterima. Dengan kata lain kepemilikan institusional memiliki pengaruh terhadap pengungkapan corporate social responsibility. Hal ini dapat terjadi karena pengungkapan CSR ini merupakan sesuatu yang bersifat voluntary bagi suatu perusahaan, sesuai dengan teori stakeholders bahwa stakeholder pada dasarnya yang dapat mengendalikan atau memiliki kemampuan untuk mempengaruhi pemakaian sumber-sumber ekonomi yang digunakan perusahaan. Oleh karena itu pihak yang lebih banyak memiliki kepentingan dan kewenangan mengenai hal tersebut salah satunya adalah pihak pemegang saham institusi. Pihak dari pemegang saham tersebut yang akan memutuskan bagaimana pengungkapan CSR akan dilakukan yang seluruh kepentingan yang terkait tentang hal tersebut. Selanjutnya dijelaskan dengan teori stakeholders yang mengatakan bahwa perusahaan bukanlah entitas yang hanya beroperasi untuk kepentingannya sendiri namun harus memberikan manfaat bagi stakeholdemya.

Selanjutnya hipotesis kedua yang menyatakan komisaris independen berpengaruh terhadap pengungkapan corporate social responsibility ditolak, dengan kata lain komisaris independen tidak memiliki pengaruh terhadap pengungkapan corporate social responsibility. Hipotesis tiga yang menyatakan komposisi komite audit berpengaruh terhadap pengungkapan corporate social responsibility ditolak, sehingga dapat disimpulkan bahwa komposisi komite audit tidak memiliki pengaruh terhadap pengungkapan corporate social responsibility. Menurut peneliti hasil tersebut dapat terjadi karena komisaris independen itu sendiri adalah anggota komisaris yang tidak terafiliasi dengan manajemen, anggota dewan komisaris lainnya dan pemegang saham pengendali, serta bebas dari hubungan bisnis atau hubungan lainnya yang dapat mempengaruhi kemampuannya untuk bertindak independen. Komite audit merupakan pihak independen yang berasal dari luar perusahaan. Kedua pihak ini memiliki kesamaan yang merupakan pihak independen yang tidak memiliki hubungan afiliasi dengan pihak perusahaan. Dengan fungsi atau peran komisaris independen dan komposisi komite audit adalah sebagai pengontrol pelaporan untuk pelaporan keuangan yang bersifat mandatory yang dilihat dari tingkat akuntabilitasnya sehingga tidak memiliki banyak kepentingan untuk terlibat dalam pengungkapan CSR seperti halnya pemegang saham institusional. 


\section{KESIMPULAN DAN SARAN}

Penelitian ini bertujuan untuk menguji pengaruh makanisme corporate governance terhadap CSR. Studi dilakukan pada perusahaan yang termasuk dalam indek SRI-KEHATI dengan periode pengamatan 2011-2014 dengan jumlah sampel 18 perusahaan dan menggunakan alat analisis regresi linear berganda. Hasil penelitian menunjukkan bahwa komite audit dan komisaris independen tidak berpengaruh terhadap CSR. Hal ini dikarenakan komite audit dan komisaris independen yang merupakan pihak independen yang tidak memiliki hubungan afiliasi dengan pihak perusahaan. Fungsi atau peran komisaris independen dan komposisi komite audit adalah sebagai pengontrol pelaporan untuk pelaporan keuangan yang bersifat mandatory bukan voluntary. Sedangkan kepemilikan institusional berpengaruh terhadap CSR. Hal ini dikarenakan kepemilikan institusional memiliki banyak kepentingan terhadap perudsahaan oleh karena itu memiliki banyak pengaruh terhadap pelaporan keuangan yang bersifat mandatory maupunpengungkkapan CSR yang bersifat voluntary. Oleh karena itu saran bagi peneliti selanjutnya untuk menjadikan peran komisaris independen dan komite audit sebagai variabel moderating.

\section{DAFTAR PUSTAKA}

Anggraini, Fr. Reni Retno. 2006. Pengungkapan Informasi Sosial dan FaktorFaktor yang Mempengaruhi Pengungkapan Informasi Sosial dalam Laporan Tahunan. SNA IX. Padang.

Faqih, Mansyur. 2010. Dasari CSR dengan Etika Bisnis. www.republika.co.id (diakses tanggal 3 Mei 2011).

Freundlieb, M. \& Teuteberg, F. (2012). Evaluating the quality of web based sustainability reports: a multi-method framework. Disampaikan pada 45th Hawaii International Conference on System Sciences. Diakses pada 19 April 2012 dari :

http://secure3.computer.org/csdl/proceedings/hicss/2012/4525/00/4525b177 - abs.html

Ghozali, Imam. 2006. Aplikasi Analisis Multivariate dengan Program SPSS. Edisi 4. BP-UNDIP: Semarang. 
Akram, Animah, \& Prayitno Basuki : Pengungkapan Corporate Social...

Handayani, Ari Retno. 2010. Pengaruh Environmental Performance terhadap Environmental Disclosure dan Economic Performance serta Environmental Disclosure terhadap Economic Performance. Universitas Diponegoro: Semarang.

Nilawaty. 2011. Perbandingan Pengaturan Tentang Corporate Social Responsibility Antara Indonesia dengan Cina dalam Upaya Perwujudan Prinsip Good Corporate Governance di Indonesia. Universitas Sumatera Utara : Medan.

Nurkhin, Ahmad. 2010. Corporate Governance dan Profitabilitas; Pengaruhnya terhadap Pengungkapan CSR Sosial Perusahaan. Jurnal Dinamika Akuntansi Vol 2 No1 Universitas Surakarta: Solo

Rustiarini, Wayan. 2010. Pengaruh Corporate Governance pada Hubungan Corporate Social Responsibility dan Nilai Perusahaan. SNA XIII Purwokerto.

Sembiring, Eddy Rismanda. 2005. Karakteristik Perusahaan dan Pengungkapan Tanggung Jawab Sosial: Studi Empiris pada Perusahaan yang Tercatat di Bursa Efek Jakarta. SNA VIII Solo.

Siswantaya, I Gde. 2007. Mekanisme Corporate Governace dan Manajemen Laba (Studi pada Perusahaan-Perusahaan yang Terdaftar di Bursa Efek Jakarta). Universitas Diponegoro: Semarang.

Viera, Ines Silva dan Maria Joao Jorge. 2009. Corporate Governance, Ethics and Social Responsibility: Comparing Continental European and AngloSaxon Firms. Portugal.

Waryanto, 2010. Pengaruh Karakteristik Good Corporate Governance (GCG) terhadap Luas Pengungkapan Corporate Social Responsibility (CSR) di Indonesia. Universitas Diponegoro: Semarang. 